\title{
Aging from the perspective of racism and other forms of discrimination: influences of institutional and structural determinants on the lives of older adults
}

The area of gerontology and geriatrics has grown a great deal in recent years. This is due to the advanced levels of training of professionals who work in the area, the interest demonstrated by those entering the field and the growing demand for services from the emerging population of older Brazilian adults. The challenges and changes are innumerable and influence every sphere: education, health, work, leisure, conjugality, sexuality, political participation, residences and neighborhoods.

It was also observed in 2019 that academia, both in terms of its institutions and in its student and teaching bodies, through public as well as private services, involving both leaders and collaborators, has not yet fully embraced the new challenges of today, especially with regard to the need to alter the life courses of social groups that face great difficulties when aging. This is the subject that this editorial dares to tackle.

Historically, the foundations that structure Brazilian society have been hidden: racism, patriarchy, sexism, the determination of social classes and religiosity. For years we have tried to hide these structures as though they are small, blunt pins. However, such determinants create situations that not only reveal the differences between social groups, but are markers of inequalities, occurring repeatedly and systematically, generating life courses for social groups such as black and brown-skinned Brazilians and indigenous people whose finishing line often arrives prior to old age. Many such black Brazilians die young ${ }^{1}$, suffer functional disabilities earlier, reside in areas that lack opportunities for active aging ${ }^{2}$, live alone through no choice of their $\mathrm{own}^{2}$, some are forced to hide their sexual identity or live apart from the person they love, and finally, many will not live to see 60 because of these social determinants! On the other hand, and this is something that has been extensively studied, there are groups of ninety or one hundred year old people who, in the vast majority of cases, are white, and so do not face the structural barriers imposed by Brazilian society, obtaining access to effective public and private services, eating healthy food, living in neighborhoods that promote wellness and other practices consistent with our guidelines and systematic reviews.

Many health practitioners and researchers do not attempt to understand the "failures or shortcomings" of our practices and epistemologies. There are limitations to scientific knowledge, as well as ignorance and a lack of validation of the folk-knowledge possessed by the broad range of older adult social groups, which, if respected, could change therapeutic itineraries and perspectives of life ${ }^{3}$.

Such determinants are fearsome demons, yet are invisible to the eyes of many. I invite RBGG readers and authors to reflect on a number of issues, namely: do educational institutions include in their curricula the social determinations of health, disease and care, taking into account the racial, ethnic, age and gender 
diversity of Brazil? How many students in higher education devote an extended part of their study timetable to aging, rather than allocating the minimum of hours to the subject, as is common? Do our health services know how to properly conjugate the verbs "get old", conceptualized by the writer Oswaldo Faustino, or "gerontologize", or in other words, are our services oriented to the logic of aging, using appropriate indicators such as functional disability and its intersections with ethnicity/skin color and gender, creating specific priorities and lines of care for each group of older adults? Do our health professionals know how to properly receive and treat a poor black older woman or an older gay couple? How can we review our rehabilitation services, which today should be one of the priorities of Primary Care for the elderly, especially for the poor, who have to continue working to meet their daily costs of living? What about leisure activities, which have not yet been adopted by many of our black older adults? How can we have services that meet the real desires of older adults and their cultural and ethnic values, such as quilombolas (Afro-Brazilian residents of settlements first established by escaped slaves) and various indigenous tribes? Are we aware that all of this should be part of the Brazilian Research Priority Agenda? ${ }^{4}$

This editorial therefore seeks to raise questions and provide certain answers about how we must urgently review our practices and knowledge if we are to understand black or indigenous adults who strive to live beyond 60 and, with constant support and dialogue, include practices of equity in our activities, thereby reducing inequities, such as the institutionalized or unconscious prejudices that many still possess. It is by understanding that we are not equal but different, and that this difference has generated inequality and inequity, and through policies, services and activities geared to addressing racism, sexism and other structuring determinants, that we will succeed.

\section{Alexandre da Silva}

Adjunct Professor, Jundiai Medical School, Member of ABRASCO Racism and Health Working Group and of the International Center for Longevity (ILC - Brasil)

\section{REFERENCES}

1. Fiorio NM, Flor LS, Padilha M, de Castro DS, Molina MDCB. Mortalidade por raça/cor: evidências de desigualdades sociais em Vitória (ES), Brasil. Rev Bras Epidemiol. 2011;14(3):522-30.

2. Da Silva A, Rosa TEC, Batista LE, Kalckmann S, Louvison MCP, Teixeira DSC, et al. Iniquidades raciais e envelhecimento:análise da coorte 2010 do Estudo Saúde,Bem-Estar e Envelhecimento (SABE). Rev Bras Epidemiol. 2019;21(suppl 2):E180004 [14 p.].

3. Williams DR, Priest N. Racismo e saúde : um corpus crescente de evidência internacional. Sociologias. 2015;17(40):124-74.

4. Brasil. Ministério da Saúde. Secretaria de Ciência T e IED de C e T. Agenda de Prioridades de Pesquisa Do Ministério Da Saúde - APPMS [Internet]. Brasília, DF: MS; 2018 [acesso em 29 set. 2018]. Disponível em: http:// bvsms.saude.gov.br/bvs/publicacoes/agenda_prioridades_pesquisa_ms.pdf 